Agroradix Vol. 3 No.1 Desember (2019)

ISSN : 2621-0665

\title{
Kajian Macam Pupuk Majemuk dan Organik Cair Terhadap Pertumbuhan dan Produksi Tanaman Padi (Oryza Sativa L.)
}

\author{
Choirul Anam, Desi Ayu Ratnawida, dan Mariyatul Qibtiyah \\ Prodi Agroteknologi Fakultas Pertanian Universitas Islam Darul 'Ulum Lamongan Jawa Timur
}

Korespondensi : choirul.anam19@yahoo.com

\begin{abstract}
ABSTRAK
Penelitian ini dilaksanakan di Dusun Bubuk Desa Mayangkawis Kecamatan Balen Kabupaten Bojonegoro. Penelitian ini menggunakan Rancangan Acak Kelompok (RAK) pola faktorial dengan 3 ulangan, yang terdiri dari 2 faktor yaitu: Macam Pupuk Organik Cair dan Macam Pupuk Majemuk. Faktor perlakuan macam pupuk organik cair terdiri dari 3 perlakuan yaitu: Tanpa Pupuk Organik Cair, POC Biourine Sapi, dan POC Supermax. Faktor Pupuk Majemuk terdiri dari 3 level yaitu : Tanpa Pupuk Majemuk, Pupuk NPK Phonska, dan Pupuk NPK Mutiara.Indikator pertumbuhan dan produksi yang diamati meliputi : tinggi tanaman, jumlah anakan per rumpun, jumlah malai, jumlah anakan produksi, berat gabah per hektar, dan berat gabah 1000 bulir. Pengamatan dilaksanakan mulai umur 14 hari dengan interval 7 hari sekali.Tujuan dari penelitian ini adalah untuk mengetahui pengaruh efektivitas pemberian macam pupuk majemuk dan organik cair terhadap pertumbuhan dan produksi tanaman padi (Oryza sativa L.). Data hasil dari penelitian sejak tanaman berumur 14 hari hingga akhir pengamatan, dianalisa dengan sidik ragam dan dilanjutkan dengan Uji BNT 5\%.Dari hasil pengamatan dan perhitungan melalui analisa sidik ragam dapat diambil kesimpulan bahwa adanya interaksi yang sangat nyata pada perlakuan macam pupuk majemuk dan macam pupuk organik cair pada parameter tinggi tanaman (14 dan $42 \mathrm{hst}$ ), jumlah anakan per rumpun (14 dan 42 hst), jumlah malai (50 dan 65 hst), dan berat gabah perhektar. Didapat beda sangat nyata terhadap perlakuan macam pupuk majemuk dan macam pupuk organik cair pada parameter tinggi tanaman (14, 28, dan 42 hst), jumlah anakan per rumpun (14, 28, dan 42 hst), jumlah anakan produktif ( 50 dan 65 hst), dan berat gabah 1000 bulir. Perlakuan POC biourine sapi dan pupuk NPK Mutiara menghasilkan nilai yang lebih baik dari perlakuan lainnya.
\end{abstract}

Kata Kunci : Pupuk Organik Cair, Pupuk Majemuk, Padi.

\section{ABSTRACT}

This research was carried out in Bubuk Hamlet, Mayangkawis Village, Balen District, Bojonegoro Regency. This study uses a factorial randomized block design (RBD) with 3 replications, consisting of 2 factors, namely: Types of Liquid Organic Fertilizers and Types of Compound Fertilizers. The treatment factor for the types of liquid organic fertilizer consists of 3 treatments, namely : Without Liquid Organic Fertilizer, Biourine Cow POC, and Supermax POC. Compound Fertilizer Factors consist of 3 levels, namely : Without Compound Fertilizer, NPK Phonska Fertilizer, and NPK Pearl Fertilizer. Indicators of growth and production observed include : plant height, number of tillers per clump, number of panicles, number of tillers, weight of grain per hectare, and grain weight of 1000 grains. Observations carried out starting at the age of 14 days with 7 days intervals. The purpose of this study was to determine the effect of the effectiveness of the provision of liquid and organic compound fertilizer on the growth and production of rice plants (Oryza sativa L.). Data from the results of the study since the plants were 14 days old until the end of the observation were analyzed by variance and followed by a $5 \%$ BNT Test. From the results of observations and calculations through analysis 
Agroradix Vol. 3 No.1 Desember (2019)

ISSN : 2621-0665

of variance, it can be concluded that there is a very real interaction on the treatment of various types of compound fertilizers and kinds of liquid organic fertilizer on plant height parameters ( 14 and $42 \mathrm{hst}$ ), number of tillers per clump (14 and 42 days after planting), number of panicles (50 and 65 days), and grain weight per hectare. Very significant differences were found in the treatment of various types of compound fertilizers and kinds of liquid organic fertilizer on plant height parameters $(14,28$ and 42 days after planting), number of tillers per clump (14, 28 and 42 days after planting), number of productive tillers (50 and 65 days after planting). ), and grain weight of 1000 grains. The treatment of cattle biourine POC and Pearl NPK fertilizer produced a better value than other treatments.

Keywords : Liquid Organic Fertilizer, Compound Fertilizer, Rice.

\section{PENDAHULUAN}

Indonesia merupakan negara agraria, yang mana penduduk Indonesia lebih didominasi dengan pekerjaan praksis sebagai seorang petani. Banyaknya lahan yang masih kosong dan apabila digunakan untuk sarana produksi pertanian, pasti akan mampu meningkatkan kesejahteraan di bidang ekonomi dan pembangunan. Selain itu jika ditinjau dari letak geografis Indonesia, maka tanah di Indonesia memiliki tingkat kesuburan yang tinggi. Sehingga sangat strategis apabila lahan tersebut dimanfaatkan untuk pertanian dan perkebunan. Adapun dari berbagai macam tanaman yang cocok untuk di seiring dengan pertumbuhan penduduk yang lebih cepat dari pertumbuhan produksi pangan yang tersedia. Pengaturan sistem tanam dan umur bibit yang sesuai, dan penggunaan varietas unggul padi yang efektif terhadap pertumbuhan tanaman juga efesien dalam waktu mendapatkan produktivitas yang optimal (Anonymous, 2012).

Selain itu, dengan pemberian larutan pupuk organik cair yang disemprotkan pada tanaman berfungsi sebagai bioaktivator perombakan bahan organik, untuk menambah ketersediaan unsur hara makro dan mikro secara optimal bagi tanaman (Anonymous, 2007).

Beberapa penelitian menunjukan dengan pemberian pupuk organik cair pada tanaman, dapat meningkatkan produksi tanaman termasuk tanaman padi melalui kelola adalah tanaman pangan salah satunya yaitu padi. Padi (Oryza Sativa L.) merupakan tanaman pertanian kuno yang sampai sekarang menjadi tanaman penghasil bahan pangan pokok dinegara daerah tropis, terutama di Asia dan Afrika (Herawati, W. D., 2012).

Produksi komoditas tanaman padi di Kabupaten Bojonegoro Jawa Timur, terus mengalami peningkatan hingga mencapai surplus. Menurut data BPS Bojonegoro tahun 2015, produksi tanaman padi dari tahun 2011 mencapai 707.970 per ton dan mengalami kenaikan pada tahun 2013 hingga mencapai 802.528 per ton. Kebutuhan akan beras terus meningkat

aktivasi mikroorganisme yang terkandung didalamnya maupun di lingkungan (Suriadikarta, dkk. 2006).

Sebagian besar para petani di wilayah Kabupaten Bojonegoro khususnya Desa Mayangkawis Dusun Bubuk berpendapat bahwa pertumbuhan padi yang menggunakan pupuk anorganik lebih berkualitas, sedangkan sebagian kecil masyarakat setempat bahwa menggunakan pupuk organik lebih menguntungkan karena dapat menghemat biaya. Berawal dari adanya asumsi tersebut, maka penulis akan melakukan penelitian ini dengan judul "Kajian Macam Pupuk Majemuk dan Organik Cair Terhadap Pertumbuhan dan Produksi Tanaman Padi (Oryza Sativa L.)". 
Agroradix Vol. 3 No.1 Desember (2019)

ISSN : 2621-0665

\section{METODOLOGI PENELITIAN}

\section{Waktu dan Tempat}

Penelitian dilaksanakan di Desa Mayangkawis, Kecamatan Balen, Kabupaten Bojonegoro. Ketinggian tempat \pm 6 meter dpl. Waktu penelitian di laksanakan bulan Januari sampai April 2019.

\section{Bahan dan Alat}

Bahan yang digunakan adalah benih tanaman padi varietas INPARI 32serta macam pupuk majemuk (NPK Phonska, NPK Mutiara) dan macam pupuk organik cair (Biourine sapi, POC SuperMAX).Alat-alat yang digunakan yaitu traktor, handsprayer, mulsa putih bening, cangkul, sabit, meteran, tali rafia, papan nama, alat tulis, dan alat penunjang lainnya.

\section{Rancangan Penelitian}

Penelitian ini menggunakan Rancangan Acak Kelompok (RAK) dengan polafaktorial dengan 3 ulangan, yang terdiri dari 2 faktor yaitu : Macam Pupuk Organik Cair dan Macam Pupuk Majemuk. Faktor perlakuan macampupuk organik cair terdiri dari 3 perlakuan yaitu: Tanpa Pupuk Organik Cair, POC Biourine Sapi, danPOC SuperMax. Faktor macam pupuk majemuk terdiri dari 3 levelyaitu: Tanpa Pupuk Majemuk, Pupuk NPK Phonska,dan Pupuk NPK Mutiara.

\section{Pelaksanaan Penelitian}

Pengolahan Tanah

Pengolahan tanah dilakukan dengan cara yaitu menggunakan hand traktor serta membuat saluran dan petakan, serta meratakan tanah. petakan dibuat dengan ukuran 2 meter $\times 2$ meter. Persiapan lahan untuk tanaman padi ditentukan oleh kondisi tanah sebelum pelaksanaan penanaman, setiap jarak atau blok pada percobaan dibatasi dengan lebar $1 \mathrm{~m}$ sehingga bila hujan turun tanaman tidak akan terjadi genangan air.

\section{Persemaian}

Benih padi yang digunakan adalah varietas padi INPARI 32 yang telah bersertifikat/berlebel. Kebutuhan benih padi berkisar $30-40 \mathrm{~kg} / \mathrm{ha}$, dan luas lahan seluas $2500 \mathrm{~m}^{2}$ dari luas lahan yang akan ditanami. Sebelum penaburan benih di lahan persemaian, terlebih dahulu benih direndam dalam air dalam waktu 24 jam. Kemudian setelah benih padi mulai ada titik tumbuh kemudian ditaburkan di atas tanah persemaian yang telah disiapkan.

\section{Pemindahan bibit}

Pemindahan bibit dilakukan pada umur 23 hari dipersemaian. Pemindahan dilakukan secara langsung dengan menggunakan tangan dan diikat sesuai dengan keinginan, kemudian diletakkan ditiap petak lahan.

\section{Penanaman}

Penanaman langsung ditanam dengan tangan dengan kedalaman $3 \mathrm{~cm}$ dan kondisi air yang cukup, penanaman padi yang terlalu dalam dapat menyebabkan pertumbuhan akar terhambat dan anakan semakin berkurang, yang nantinya produksi akan berkurang. Penanaman dilakukan dengan posisi bibit yang tegak dengan jumlah tanaman satu lubang 3 sampai 4 batang bibit/rumpun dengan jarak tanam sistem jajar legowo (jarwo) $4: 1$ yakni dengan menggunakan jarak tanam $2 \mathrm{~m} \times 2 \mathrm{~m}$ dan jarak perbaris $0,5 \mathrm{~m}$.

\section{Penyulaman}

Penyulaman dilakukan dengan mengganti tanaman yang tidak bisa tumbuh secara baik atau mati yang dilakukan ketika umur tanaman 7 hari setelah tanam, dengan tujuan agar pertumbuhan tanaman lebih seragam.

\section{Pengairan}

Metode pemberian air pada tanaman padi sawah adalah pada saat tanam sampai 3 hari setelah tanam dengan 
Agroradix Vol. 3 No.1 Desember (2019)

ISSN : 2621-0665

kondisi air cukup. Dimana saat umur 4 hari setelah tanam sampai 10 hari setelah tanam, dengan kondisi air setinggi $5 \mathrm{~cm} .11$ hari setelah tanam sampai memanjang berbunga dan air dibiarkan mengering sendiri selama 5 hari, setelah kering pemberian air setinggi $5 \mathrm{~cm}$ dan kemudian dibiarkan lagi mengering sendiri, dan saat memasuki fase pembungaan sampai umur 10 hari sebelum panen hingga petakan dikeringkan.

\section{Pemupukan}

Selama pertumbuhan tanaman padi dilapangan membutuhkan ketersediaan unsur hara yang cukup melalui pemupukan. Adapun dalam penelitian ini pupuk yang diberikan pada tanaman padi meliputi macam pupuk majemuk dan organik cair, yaitu :

\section{- Pupuk NPK Phonska :}

Pemberian pupuk diberikan 3 kali yaitu pupuk susulan ke-1 dengan jangka waktu 7 hst dengan takaran $300 \mathrm{~kg} / \mathrm{ha}$, kemudian di lanjutkan dengan pemberian pupuk susulan ke-2 dengan jangka waktu umur 21 hst dengan takaran sama yaitu $300 \mathrm{~kg} / \mathrm{ha}$, dan pemberian pupuk susulan ke-3 dengan jangka waktu 35 hari setelah tanam dengan dosis $300 \mathrm{~kg} / \mathrm{ha}$. Jika dihitung dengan dosis yang diberikan yaitu 120gr/petak.

\section{- $\quad$ Pupuk NPK Mutiara}

Dalam penelitian ini pupuk NPK Mutiara diberikan sebanyak $3 x$ dengan jangka waktu yaitu umur 7 hst , 21 hst, dan $35 \mathrm{hst}$ dengan dosis $300 \mathrm{~kg} / \mathrm{ha}$. Jika dihitung dengan dosis yang diberikan yaitu $120 \mathrm{gr} /$ petak.

\section{- $\quad$ POC Biourine Sapi}

Biourine sapi diaplikasikan dengan cara disemprotkan pada daun tanaman, diberikan saat tanaman berumur umur 7 hst dengan interval 7 hari sekali sampai tanaman padi berumur 21 hst dengan dosis 1500 liter/ha. Jika dihitung dengan konsentrasi yang diberikan yaitu $600 \mathrm{ml} /$ petak.

\section{- POC SuperMAX}

POC SuperMAX diberikan mulai umur 7 hst dengan interval 7 hari sekali. POC SuperMAX diaplikasikan dengan cara disemprotkan pada daun tanaman, yang diberikan sampai tanaman berumur 21 hst dengan dosis 1500 liter/ha. Jika dihitung dengan konsentrasi yang diberikan yaitu $600 \mathrm{ml} /$ petak.

\section{Penyiangan}

Penyiangan dilakukan secara manual yaitu dengan cara mencabut gulma disekitar tanaman padi yang dilakukan secara langsung dengan tangan atau menggunakan alat tradisional (garok). Penyiangan tanaman padi dapat dilakukan setiap 1 minggu sekali namun jika dalam waktu kurang dari 1 minggu sudah tumbuh gulma disekitar tanaman padi, maka dapat dilakukan penyiangan, jadi penyiangan dapat dilakukan setiap saat, tidak harus diberi selang waktu karena keberadaan adanya gulma dapat memberikan persaingan dan perebutan unsur hara antara tanaman padi yang dibudidayakan dengan gulma tersebut, yang nantinya akan mempengaruhi pertumbuhan dan produksi tanaman padi yang dibudidayakan.

\section{$\begin{array}{lll}\text { Pengendalian OPT } & \text { (Organisme }\end{array}$ Pengganggu Tanaman)}

Pengendalian hama penyakit tanaman dilakukan dengan menggunakan pestisida berupa fungisida dan insektisida dilakukan secara rutin apabila terjadi serangan dari hama dan penyakit.

\section{Pemanenan}

Pemanenan dilakukan apabila semua bulir padi telah menguning. Kegiatan pemanenan dilakukan dengan menggunakan alat panen yang tradisional yaitu dengan menggunakan perontok, hal ini dilakukan karena cara pemanenan antara petak perlakuan satu dengan lainnya dipisahkan, tujuannya supaya diketahui sistem jarak tanam dan perlakuan sama seperti apa yang nantinya dapat memberikan produksi yang tinggi dan dilakukan ketika tanaman berumur 90 
Agroradix Vol. 3 No.1 Desember (2019)

ISSN : 2621-0665

sampai 95 hari setelah tanam yang ditandai dengan buahnya yang padat, kemudian dari warnanya yang kuning keemasan.

\section{HASIL DAN PEMBAHASAN}

\section{Tinggi Tanaman}

Berdasarkan hasil analisa sidik ragam menunjukan bahwa terdapat interaksi antara perlakuan macam pupuk majemuk dan organik cair terhadap pertumbuhan tinggi tanaman pada pengamatan umur 14, 28 dan umur 42 hari setelah tanam. Hasil uji BNT 5\% menunjukkan adanya perbedaan antar perlakuan (Tabel 1).

Tabel 1. Rata-rata tinggi tanamanpada umur 14 hst, 28 hst, dan 42 hst.

\begin{tabular}{lccc}
\hline \multirow{2}{*}{\multicolumn{1}{c}{ Perlakuan }} & \multicolumn{3}{c}{ Rata-rata Tinggi Tanaman (cm) Pada Pengamatan } \\
& \multicolumn{3}{c}{ Umur } \\
\cline { 2 - 4 } & $14 \mathrm{hst}$ & $28 \mathrm{hst}$ & $42 \mathrm{hst}$ \\
\hline Tanpa POC + Tanpa Pupuk Majemuk & $35,80 \mathrm{bc}$ & $57,20 \mathrm{~b}$ & $72,27 \mathrm{~b}$ \\
Tanpa POC + NPK Phonska & $35,80 \mathrm{bc}$ & $58,93 \mathrm{~b}$ & $71,93 \mathrm{~b}$ \\
Tanpa POC + NPK Mutiara & $35,73 \mathrm{bc}$ & $58,33 \mathrm{~b}$ & $72,53 \mathrm{~b}$ \\
Biourine Sapi + Pupuk Majemuk & $35,27 \mathrm{bc}$ & $57,87 \mathrm{~b}$ & $75,53 \mathrm{~b}$ \\
Biourine Sapi +NPK Phonska & $36,93 \mathrm{~b}$ & $58,87 \mathrm{~b}$ & $73,33 \mathrm{~b}$ \\
Biourine Sapi + NPK Mutiara & $40,93 \mathrm{a}$ & $65,40 \mathrm{a}$ & $84,27 \mathrm{a}$ \\
SuperMax + Tanpa Pupuk Majemuk & $35,33 \mathrm{bc}$ & $58,27 \mathrm{~b}$ & $73,87 \mathrm{~b}$ \\
Super Max + NPK Phonska & $35,27 \mathrm{bc}$ & $58,13 \mathrm{~b}$ & $73,80 \mathrm{~b}$ \\
SuperMax +NPK Mutiara & $34,80 \mathrm{c}$ & $59,40 \mathrm{~b}$ & $71,53 \mathrm{~b}$ \\
\hline \multicolumn{1}{c}{ BNT 5\% } & 2,09 & 2,79 & 5,31 \\
\hline
\end{tabular}

Keterangan : Angka-angka yang diikuti huruf sama dalam kolom yang sama tidak berbeda nyata dengan uji BNT 5\%

Pada Tabel 1. menunjukan bahwa perlakuan terbaik didapatkan pada perlakuan biourine sapi dan NPK Mutiara pada pengamatan umur 14 hst, 28 hst, dan 42 hst.

dapat dilakukan dengan menggunakan pupuk organik cair. Substitusi ini dapat meningkatkan pertumbuhan tinggi pada tanaman, jumlah anakan, dan bobot jerami padi yang setara dengan pemberian pupuk $\mathrm{N}, \mathrm{P}, \mathrm{K}$.
Pemberian pupuk organik cair terhadap tanaman padi akan mempercepat proses sintesis asam amino dan protein sehingga mempercepat pertumbuhan tanaman padi. Nurjaya, Setyorini (2008) meneliti substitusi pada pupuk kimia

\section{Jumlah Anakan Per rumpun}

Hasil analisa sidik ragam menunjukan bahwa terdapat interaksi antara perlakuan macam pupuk majemuk dan organik cair pada pengamatan jumlah anakan per rumpun umur 14 hst, 28 hst dan umur 42 hst. Hasil uji BNT 5\% seperti tabel dibawah ini (Tabel 2). 
Agroradix Vol. 3 No.1 Desember (2019)

ISSN : 2621-0665

Tabel 2. Rata-rata jumlah anakan per rumpun pada umur 14 hst, 28 hst, dan 42 hari setelah tanam

\begin{tabular}{lccc}
\hline \multirow{2}{*}{ Perlakuan } & \multicolumn{3}{c}{ Rata-rata jumlahanakan Pada Pengamatan Umur } \\
\cline { 2 - 4 } & $14 \mathrm{hst}$ & $28 \mathrm{hst}$ & $42 \mathrm{hst}$ \\
\hline Tanpa POC + Tanpa Pupuk Majemuk & $8,07 \mathrm{~b}$ & $12,73 \mathrm{i}$ & $20,07 \mathrm{bc}$ \\
Tanpa POC + NPK Phonska & $8,13 \mathrm{~b}$ & $16,80 \mathrm{bcdefgh}$ & $20,60 \mathrm{bc}$ \\
Tanpa POC + NPK Mutiara & $8,33 \mathrm{~b}$ & $18,33 \mathrm{bcd}$ & $19,60 \mathrm{bc}$ \\
Biourine Sapi + Pupuk Majemuk & $7,93 \mathrm{~b}$ & $18,73 \mathrm{bc}$ & $20,87 \mathrm{ab}$ \\
Biourine Sapi +NPK Phonska & $8,60 \mathrm{~b}$ & $19,60 \mathrm{~b}$ & $20,80 \mathrm{bc}$ \\
Biourine Sapi + NPK Mutiara & $11,00 \mathrm{a}$ & $25,33 \mathrm{a}$ & $25,00 \mathrm{a}$ \\
SuperMax + Tanpa Pupuk Majemuk & $8,07 \mathrm{~b}$ & $17,53 \mathrm{bcdef}$ & $20,13 \mathrm{bc}$ \\
Super Max + NPK Phonska & $8,53 \mathrm{~b}$ & $17,47 \mathrm{bcdefg}$ & $19,20 \mathrm{c}$ \\
SuperMax +NPK Mutiara & $8,67 \mathrm{~b}$ & $17,67 \mathrm{bcde}$ & $20,33 \mathrm{bc}$ \\
\hline \multicolumn{1}{c}{ BNT 5\% } & 0,68 & 2,75 & 1,65
\end{tabular}

Keterangan : Angka-angka yang diikuti huruf yang sama dalam kolom sama tidak beda nyata dengan uji BNT 5\%

Jumlah anakan padi per rumpun yang terlalu banyak akan dapat mengakibatkan masa masak malai padi tidak serempak, sehingga dapat menurunkan produktivitas dan mutu beras. Jumlah anakan padi yang sedikit diharapkan malai masak serempak. Namun jika jumlah gabah padi per malai banyak maka pemasakan akan lebih lama, sehingga mutu beras padi akan menurun dan tingkat kehampaan tinggi karena ketidak mampuan sumber mengisi limbung. Jika jumlah anakan padi sedikit,

Tabel 3. Rata-rata jumlah malai pada umur 50 dan 64 hari setelah tanam

\begin{tabular}{lcc}
\hline \multirow{2}{*}{ Perlakuan } & Rata-rata Jumlah Malai Pada Pengamatan Umur \\
\cline { 2 - 3 } & $\mathbf{5 0} \mathbf{~ h s t}$ & $\mathbf{6 4} \mathbf{~ h t ~}$ \\
\hline Tanpa POC + Tanpa Pupuk Majemuk & $10,00 \mathrm{~b}$ & $11,27 \mathrm{~b}$ \\
Tanpa POC + NPK Phonska & $8,40 \mathrm{bc}$ & $10,80 \mathrm{~b}$ \\
Tanpa POC + NPK Mutiara & $6,67 \mathrm{c}$ & $10,47 \mathrm{~b}$ \\
Biourine Sapi + Pupuk Majemuk & $8,53 \mathrm{bc}$ & $12,07 \mathrm{~b}$ \\
Biourine Sapi +NPK Phonska & $8,87 \mathrm{bc}$ & $11,73 \mathrm{~b}$ \\
Biourine Sapi + NPK Mutiara & $13,73 \mathrm{a}$ & $20,20 \mathrm{a}$ \\
SuperMax + Tanpa Pupuk Majemuk & $7,47 \mathrm{bc}$ & $10,67 \mathrm{~b}$ \\
Super Max + NPK Phonska & $7,60 \mathrm{bc}$ & $11,20 \mathrm{~b}$ \\
SuperMax +NPK Mutiara & $5,93 \mathrm{c}$ & $9,53 \mathrm{~b}$ \\
\hline BNT 5\% & 3,28 & 4,09 \\
\hline
\end{tabular}

Keterangan : Angka-angka yang diikuti huruf sama dalam kolom sama, maka tidak beda nyata dengan uji BNT 5\% serta ada serangan hama yang dapat mengakibatkan kerusakan anakan, maka akan menurunkan hasil padi (Abdullah et al., 2005).

\section{Jumlah Malai}

Berdasarkan hasil analisis sidik ragam menunjukan terdapat interaksi antara perlakuan macam pupuk organik cair dan pupuk majemuk pada pengamatan jumlah malai umur 50dan 64 hari setelah tanam. Uji lanjutan dengan BNT 5\% (Tabel 3). 
Agroradix Vol. 3 No.1 Desember (2019)

ISSN : 2621-0665

Malai tanaman padi menopang gabah yang perlu dipenuhi dengan materi/fotosintat dari sumber dalam tanaman. Sumber (source) diartikan sebagai organ dari tanaman yang menyuplai asimilat, sedangkan limbung (sink) merupakan bagian tanaman tempat tujuan translokasi asimilat. Konsep hubungan source dan sink dapat dipakai untuk menganalisis proses produksi hasil tanaman padi. Malai padi akan mencapai hasil tinggi ketika jumlah gabah per $\mathrm{m}^{2}$ banyak, jika persentase gabah dan bobot 1000 bulir berisi tinggi. Untuk mencapai jumlah gabah yang banyak, maka dapat dilakukan dengan cara : (1) pengaturan jarak tanam yang optimal (spesifik varietas dan kesuburan tanah); (2) pemberian pupuk $\mathrm{N}$ serta bahan organik yang optimal (sesuai dengan kondisi lahan). Semakin banyak jumlah malai gabah per $\mathrm{m}^{2}$ dengan cara meningkatkan populasi tanaman, maka akan semakin pendek malai padi yang dihasilkan. Selanjutnya, jika semakin panjang malai rata-rata penanaman padi, maka akan semakin banyak jumlah gabah yang dihasilkan (A. Karim dan Suhartatik, 2009).

Dengan adanya pemberian pupuk organik cair biourine sapi dan pupuk NPK Mutiara menunjukan jumlah malai paling banyak, dan hasilnya berbeda nyata dengan perlakuan lainnya. Hal ini terjadi karena unsur hara yang diberikan berbeda tiap perlakuannya.

\section{Jumlah Anakan Produktif}

Berdasarkan hasil analisa sidik ragam bahwa terdapat interaksi antara perlakuan macam pupuk organik cair dan pupuk majemuk pada pengamatan jumlah anakan produktif umur 50dan 64 hari setelah tanam. Uji lanjutan dengan BNT 5\% seperti tabel dibawah ini (Tabel 4).

Tabel 4. Rata-rata jumlah anakan produktif umur 50 dan 64 hari setelah tanam

\begin{tabular}{lc|c}
\hline \multirow{2}{*}{ Perlakuan } & \multicolumn{2}{c}{ Rata-rata Jumlah Anakan Produktif Pengamatan } \\
\cline { 2 - 3 } & $50 \mathrm{hst}$ & $64 \mathrm{hst}$ \\
\cline { 2 - 3 } & $3,67 \mathrm{~b}$ & $6,53 \mathrm{~b}$ \\
\hline Tanpa POC + Tanpa Pupuk Majemuk & $2,80 \mathrm{bc}$ & $5,93 \mathrm{bc}$ \\
Tanpa POC + NPK Phonska & $2,67 \mathrm{bcd}$ & $5,33 \mathrm{bc}$ \\
Tanpa POC + NPK Mutiara & $2,13 \mathrm{~cd}$ & $5,73 \mathrm{bc}$ \\
Biourine Sapi + Pupuk Majemuk & $2,20 \mathrm{~cd}$ & $5,53 \mathrm{bc}$ \\
Biourine Sapi +NPK Phonska & $5,87 \mathrm{a}$ & $8,80 \mathrm{a}$ \\
Biourine Sapi + NPK Mutiara & $1,60 \mathrm{~d}$ & $5,27 \mathrm{bc}$ \\
SuperMax + Tanpa Pupuk Majemuk & $2,53 \mathrm{~cd}$ & $5,27 \mathrm{bc}$ \\
Super Max + NPK Phonska & $1,67 \mathrm{~d}$ & $4,47 \mathrm{c}$ \\
SuperMax +NPK Mutiara & 1,10 & 1,83 \\
\hline BNT 5\% & &
\end{tabular}

Keterangan : Angka-angka yang diikuti huruf sama dalam kolom sama menunjukkan tidak beda nyata dengan uji BNT 5\%

Pupuk majemuk NPK Mutiara memiliki kandungan unsur hara yang lebih lengkap, pengaplikasiannya juga lebih efisien, dari segi tenaga kerja sifatnya tidak terlalu higroskopis, sehingga tanah disimpan dan tidak akan cepat menggumpal (Ariani, 2009).

Pupuk yang mengandung unsur hara seperti Nitrogen $(N)$, Fosfor $(P)$, dan kalium (K) merupakan tiga unsur yang paling baik dan banyak diperlukan untuk tanaman padi 
Agroradix Vol. 3 No.1 Desember (2019)

ISSN : 2621-0665

yang merupakan pembatas antara pertumbuhan dan hasil tanaman padi (Tandon, 1995).

\section{Bobot Gabah Per-Hektar}

Hasil analisis sidik ragam menunjukkan adanya perbedaan nyata pada masing-masing perlakuan yaitu pada perlakuan pupuk organik cair dan pupuk majemuk pada pengamatan bobot gabah perhektar setelah panen. Hasil uji BNT 5\% seperti pada tabel dibawah ini (Tabel 5).

Tabel 5. Rata-rata bobot gabah perhektar

\begin{tabular}{lc}
\hline \multicolumn{1}{c}{ Perlakuan } & Rerata \\
\hline Tanpa POC & $1.32 \mathrm{a}$ \\
POC Biourine Sapi & $1.61 \mathrm{a}$ \\
POC SuperMax & $1.61 \mathrm{ab}$ \\
\hline \multicolumn{1}{c}{ BNT 5\% } & 0.10 \\
\hline Tanpa Pupuk Majemuk & $1.46 \mathrm{~b}$ \\
Pupuk NPK Phonska & $1.49 \mathrm{~b}$ \\
Pupuk NPK Mutiara & $1.60 \mathrm{a}$ \\
\hline \multicolumn{1}{c}{ BNT 5\% } & 0.10
\end{tabular}

Keterangan : Angka-angka yang diikuti huruf yang sama dalam kolom yang sama tidak beda nyata dengan uji BNT 5\%

Menurut Prihmantoro (2001), tanaman padi sangat membutuhkan unsur hara sebagai pemacu pertumbuhan awal yaitu nitrogen dan pupuk berimbang. Pupuk NPK secara langsung nyata untuk pertumbuhan vegetatif tanaman, tetapi harus ada sifat fisik tanah secara baik dan memberikan untuk memberikan optimalisasi penyerapan unsur hara tanah agar pertumbuhan generatifnya akan termotivasi untuk menjadi lebih baik.

\section{Bobot Gabah 1000 bulir}

Hasil analisa sidik ragam menunjukkan adanya interaksi yang sangat nyata antara perlakuan macam pupuk organik cair dan pupuk majemuk terhadap bobot gabah 1000 butir setelah panen. Hasil uji BNT 5\% seperti tabel dibawah ini (Tabel 6).

Tabel 6. Rata-rata bobot gabah 1000 bulir

Perlakuan
Rata-rata bobot gabah 1000 bulir (gr)

\begin{tabular}{lc}
\hline Tanpa POC + Tanpa Pupuk Majemuk & $0,04 \mathrm{a}$ \\
Tanpa POC + NPK Phonska & $0,05 \mathrm{a}$ \\
Tanpa POC + NPK Mutiara & $0,05 \mathrm{a}$ \\
Biourine Sapi + Pupuk Majemuk & $0,05 \mathrm{~b}$ \\
Biourine Sapi +NPK Phonska & $0,05 \mathrm{~d}$ \\
Biourine Sapi + NPK Mutiara & $0,07 \mathrm{c}$ \\
SuperMax + Tanpa Pupuk Majemuk & $0,05 \mathrm{a}$ \\
Super Max + NPK Phonska & $0,05 \mathrm{~d}$ \\
SuperMax +NPK Mutiara & $0,03 \mathrm{c}$ \\
\hline BNT 5\% & 0,01 \\
\hline
\end{tabular}


Agroradix Vol. 3 No.1 Desember (2019)

ISSN : 2621-0665

Keterangan : Angka-angka yang diikuti huruf sama dalam kolom yang sama pula tidak beda nyata dengan uji BNT 5\%

Pada Tabel 6.Perlakuan biourine sapi dan NPK Mutiaramenunjukkan hasilbobot gabah yang paling banyak.Sedangkan majemuk yang tepat, akan dapat menghasilkan produksi tanaman padi yang lebih baik.

\section{KESIMPULAN}

\section{Kesimpulan}

dilakukan pada perlakuan

Dari hasil penelitian yang telah macampupukmajemukdanorganikcairterha dappertumbuhandanproduksitanamanpadi (OryzaSativaL.)" adalahsebagaiberikut :

Hasil parameter pengamatan menunjukkan adanya interaksi perlakuan antara penggunaan pupuk organik cair dan pupuk majemuk pada parameter tinggi tanaman padi umur 14 hst dan 42 hst, serta jumlah anakan per rumpun pada umur 14 hst dan 42 hst.

Hasil parameter pengamatan menunjukkan bahwa adanya pengaruh nyata pada perlakuan pupuk organik cair terhadap jumlah malai pada umur 50 hst dan 64 hst, serta jumlah anakan produktif pada umur 50 hst dan 64 hst.

Hasil parameter pengamatan menunjukkan adanya pengaruh yang nyata pada perlakuan pupuk majemuk terhadap bobot gabah per hektar dan bobot gabah 1000 bulir.

Perlakuan pupuk organik cair biourine sapi dan pupuk NPK Mutiara menghasilkan nilai yang lebih baik daripada perlakuan lainnya.

\section{DAFTAR PUSTAKA}

Abdullah, L., P.D.M.H. Karti daan S. Hardjosoewignjo. 2005. Reposisi Tanaman Pakan dalam Kurikulum Fakultas Peternakan. Pros. Lokakarya Nasional Tanaman Pakan Ternak; Bogor, 16 bobot gabah yang paling sedikit adalah SuperMax dan NPK Mutiara. Penggunaan pupuk organik cair dan pupuk September 2005. Pusat Penelitian Dan Pengembangan Peternakan. Bogor. HIm. 11-17.

A. Karim Makarim dan E. Suhartatik. 2009. Morfologi dan Fisiologi Tanaman Padi. Balai Besar Penelitian Tanaman Padi.Sukabumi.Subang.

Ariani, Erlida. 2009. Uji Pupuk NPK 16:16:16. Jurnal BudidayaPertanian (8)1 hal 5-9. Universitas Riau.

Nurjaya dan Setyorini. D. 2008. Peranan Pupuk Organik Sipramin Sebagai Substitusi Pupuk Nitrogen terhadap Sifat Kimia Tanah dan Hasil Padi Sawah pada Inceptisol.Makalah Seminar.Departemen Agronomi danHortikultura IPB, hal. 285 296.

Prihmantoro, 2001.Kandungan Unsur Hara Tanaman Padi. Penebar Swadaya. Jakarta.

Tandon, H.L. 1995. Where Rice Devours The Land Ceres. The FAO Review ZZ : 22-29. 